\title{
Evaluation of brewer's spent grain hydrolysate as a substrate for production of thermostable $\boldsymbol{\alpha}$-amylase by Bacillus stearothermophilus
}

\author{
Rajeev Ravindran \\ Technological University Dublin, rajeev.ravindran@tudublin.ie \\ Gwilym A. Williams \\ Technological University Dublin, gwilym.williams@tudublin.ie \\ Amit Jaiswal \\ Technological University Dublin, amit.jaiswal@tudublin.ie
}

Follow this and additional works at: https://arrow.tudublin.ie/schfsehart

Part of the Biotechnology Commons, Food Biotechnology Commons, Food Chemistry Commons, and the Other Food Science Commons

\section{Recommended Citation}

Rajeev Ravindran, Gwilym A. Williams, Amit K. Jaiswal, Evaluation of brewer's spent grain hydrolysate as a substrate for production of thermostable $\alpha$-amylase by Bacillus stearothermophilus, Bioresource Technology Reports, Volume 5, 2019, Pages 141-149, ISSN 2589-014X, DOI: 10.1016/j.biteb.2019.01.004.

This Article is brought to you for free and open access by the School of Food Science and Environmental Health at ARROW@TU Dublin. It has been accepted for inclusion in Articles by an authorized administrator of ARROW@TU

Dublin. For more information, please contact

arrow.admin@tudublin.ie, aisling.coyne@tudublin.ie, gerard.connolly@tudublin.ie.

Funder: Technological University Dublin

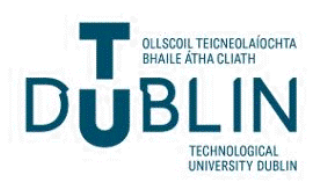




\title{
Evaluation of brewer's spent grain hydrolysate as a substrate for production of thermostable $\alpha$-amylase by Bacillus stearothermophilus
}

\author{
Rajeev Ravindran ${ }^{\mathrm{a}, \mathrm{b}}$, Gwilym A. Williams ${ }^{\mathrm{b}}$, Amit K. Jaiswal ${ }^{\mathrm{a}, *}$ \\ ${ }^{a}$ School of Food Science and Environmental Health, College of Sciences and Health, Technological University Dublin, Cathal Brugha Street, Dublin 1, Ireland \\ ${ }^{\mathrm{b}}$ School of Biological Sciences, College of Sciences and Health, Technological University Dublin, Kevin Street, Dublin 8, Ireland
}

\section{A R T I C L E I N F O}

\section{Keywords:}

Brewers spent grain

Thermostable $\alpha$-amylase

Three-step purification

Anti-biofilm agent

\begin{abstract}
A B S T R A C T
In the present study, BSG was hydrolysed using cellulolytic enzymes and used as a growth medium supplement for cultivation of the thermophilic bacterium, Bacillus stearothermophilus in the production of $\alpha$-amylase. A central composite design involving five parameters and four levels viz. starch, peptone, $\mathrm{KCl}$, and $\mathrm{MgSO}_{4}$ along with BSG hydrolysate was used to derive the optimal media composition. The fermentation was conducted using shake flasks for $36 \mathrm{~h}$ at a temperature of $50{ }^{\circ} \mathrm{C}$ and pH 7.0 at $220 \mathrm{rpm}$. Optimization trials revealed that maximal amylase production $(198.09 \mathrm{U} / \mathrm{ml})$ occurred with a medium composition of starch $(0.2 \% \mathrm{w} / \mathrm{v})$, peptone $(0.2 \%$ $\mathrm{w} / \mathrm{v}), \mathrm{KCl} \cdot 4 \mathrm{H}_{2} \mathrm{O}(0.02 \% \mathrm{w} / \mathrm{v}), \mathrm{MgSO}_{4} \cdot 7 \mathrm{H}_{2} \mathrm{O}(0.01 \% \mathrm{w} / \mathrm{v})$ and hydrolysate $(0.22 \% \mathrm{v} / \mathrm{v})$. A 1.3 -fold increase in amylase activity was obtained following novel media composition. All the factors considered in the study were found to be significant. The enzyme was purified by three step purification strategy, characterised and tested for anti-biofilm activity.
\end{abstract}

\section{Introduction}

Brewer's spent grain (BSG) is a by-product of the brewery industry. It is highly nutritious and rich in carbohydrates, protein, lignin, fibre and lipids. Every hectolitre of beer can result in $20 \mathrm{~kg}$ of BSG being produced accounting to the $\sim 85 \%$ of the total wastes generated (Laba et al., 2017). In Ireland, 760 million litres of beer are produced annually which may lead to the accumulation of approx. 152,000 tonnes of BSG (Association, 2016). BSG constitutes of $20-30 \%$ dry matter and is susceptible to microbial spoilage due to its high nutritional content. Since BSG is high in protein, fibre and the presence of trace elements such as silicon, magnesium, phosphorus and sulphur it finds wide applications as animal feed (Gregori et al., 2008; Scully et al., 2016). However, this only accounts to a small fraction of the total BSG produced making it a huge environmental burden on the brewery industry. This calls for innovative, sustainable and commercially attractive processes for its efficient valorisation.

The race to develop sustainable technology over the past several decades has led to the utilisation agro-based industry wastes such as BSG for its exploitation or bioconversion into commercially important compounds (Ravindran and Jaiswal, 2016a, 2016b; Ravindran et al., 2018a). The nutritious content and food grade quality of BSG makes it a valuable resource for the development of relevant biotechnological processes (Ravindran et al., 2018b). Since BSG is abundantly available, numerous technologies have been developed to extract value-added compounds from BSG which belong to the nature of carbohydrates, proteins or lipids. Due to its diverse composition, BSG perfectly fits into the concept of biorefinery where multiple processes of chemical, enzymatic and biotechnological in nature can be incorporated into a single production facility (Ravindran and Jaiswal, 2016b).

Due to the inherent chemical nature of BSG, it supports microbial growth and has thus been widely used for the production of enzymes. BSG has extensively been applied as a potential raw material for the production of enzymes such as amylases, amyloglucosidases, cellulases and hemicellulases. Most studies focus on the utilisation of mycelial fungi for such applications. Among bacteria, Bacillus sp. has gained considerable interest due to its ability to produce carbohydrate degrading enzymes that are of industrial importance. Some of these species such as B. subtilis, B. amyloliquefaciens, B. cereus, B. licheniformis and $B$. stearothermophilus are important due to their ability to produce $\alpha$ and $\beta$ amylases (Chen et al., 2015; Prajapati et al., 2015; Vaikundamoorthy et al., 2018). Amylases derived from Bacillus sp. find wide applications in the industry ranging from the production of fructose and glucose syrup to bakery, detergents, textile and fuel ethanol production. (Souza, 2010). Amylases hold $30 \%$ of the global enzyme market share, having largely replaced chemical hydrolysis of starch (Lal et al., 2017). Many BSG and BSG-based products have been utilised as a media component for the production of $\alpha$-amylases (Hashemi et al., 2011).

\footnotetext{
* Corresponding author.

E-mail addresses: amit.jaiswal@dit.ie, akjaiswal@outlook.com (A.K. Jaiswal).
} 
An integral component of demonstrating the economic feasibility of adopting BSG for fermentation processes is the identification of novel markets for enzyme products that can provide a sustainable return on investment. Biofilms are formed by prokaryotic microorganisms capable of producing exopolysaccharides (EPS) around the cell. Many biofilm-producing organisms are pathogenic in nature, including Vibrio cholerae, multi-drug resistant Staphylococcus aureus, and Pseudomonas aeruginosa (Costerton et al., 1999; Hall-Stoodley and Stoodley, 2005; Mihailescu et al., 2014). Biofilms produced by such microbes can cause disruption and reduction in efficiency of industrial processes. Furthermore, these pathogenic strains are responsible for $10-20 \%$ of all the hospital acquired infections (Jamal et al., 2018). Conventional preventive measures against biofilm producers include chemical biosurfactants, surface modifications and natural substances such as honey and oils. (Sadekuzzaman et al., 2015). Exopolysaccharides produced by these microbes safeguard them from attacks by antibiotics and other antimicrobial agents. However, recent studies have shown enzymes as a promising technology in the prevention of EPS production and biofilm formation. Some of the enzymes studied for this purpose include lysozyme, proteinase K, trypsin and amylase (Shukla and Rao, 2013). These enzymes have been studied individually and as cocktails as a deterrent for biofilm production (Kalpana et al., 2012).

Amylases find wide applications in the textile industry and form an integral part of detergent formulations. Starch is a strong dirt binder making ordinary detergents less effective during wash cycles. The ability of these enzymes to act upon starch makes it an appropriate solution against starchy stains. Normal wash cycles are operated at temperatures ranging from 30 to $90{ }^{\circ} \mathrm{C}$. Enzyme additives in detergent formulations are expected to be robust and active at such a wide temperature range. Furthermore, the amylases need to be stable at wide $\mathrm{pH}$ ranges and in the presence of surfactants and chelating agents. Bacillus stearothermophilus amylases and its engineered varieties have been reported to be excellent candidates for laundry detergent application (Khemakhem et al., 2009).

This study investigates the applications of BSG hydrolysate as a potential media component for the production of a thermostable $\alpha$ amylase by $B$. stearothermophilus. The growth medium composition for amylase production was optimized by the application of response surface methodology. This was followed by purification of the enzyme via a three-stage strategy. The enzyme was then characterised to determine the optimum $\mathrm{pH}$ and temperature for activity. The stability of the thermostable amylase was then determined by incubating it in various commercial detergents. Finally, initial proof-of-principle was shown for the use of the $\alpha$-amylase from B. stearothermophilus as an anti-biofilm agent using multiple bacterial strains of medical significance.

\section{Materials and methods}

\subsection{Materials}

Brewer's Spent Grain (BSG) was generously donated by Guinness Storehouse in Dublin City. The biomass was dried at $60^{\circ} \mathrm{C}$ for $18 \mathrm{~h}$ or until constant weight was achieved. The biomass was then ground and sieved to obtain a uniform particle size using a $350 \mu \mathrm{m}$ sieve. The ground BSG was then stored in a cool and dry place for further experiments. All of the chemicals required for this study such as soluble starch, peptone, beef extract, yeast extract, $\mathrm{NaCl}, \mathrm{KCl} \cdot 4 \mathrm{H}_{2} \mathrm{O}$, $\mathrm{MgSO}_{4} \cdot 7 \mathrm{H}_{2} \mathrm{O},\left(\mathrm{NH}_{4}\right)_{2} \mathrm{SO}_{4}$, DEAE-Sepharose fast-flow anion exchange resin, congo red and sucrose were purchased from Sigma-Aldrich, Ireland. Thermostable $\alpha$-amylase from Bacillus licheniformis was purchased from Megazyme, Ireland (3000 U/ml, E-BSTAA). Brain-heart infusion agar was purchased from Difco, Ireland.

\subsection{Lipid extraction from $B S G$}

The total lipid content in BSG was reduced using a modification of the protocol devised by Niemi et al. (2012). Briefly, $10 \mathrm{~g}$ of BSG was weighed, dispensed into a cellulose thimble and stoppered with cellulose wool. A Soxhlet apparatus was set up with $100 \mathrm{ml}$ of acetone in a round bottom flask and anti-bumping granules added. The extraction was conducted in reflux cycles for $5 \mathrm{~h}$. The lipid-free BSG was then dried and stored for further experiments.

\subsection{Microorganism and $\alpha$-amylase production}

Bacillus stearothermophilus LZT020 strain was supplied by the microbiology repository at the School of Food Science and Environmental Health, Dublin Institute of Technology. For seed culture, frozen glycerol stock maintained at $-80{ }^{\circ} \mathrm{C}$ was used to inoculate liquid medium containing (in g/l) peptone (3.0), yeast extract (1.5), beef extract (1.5) and $\mathrm{NaCl}$ (2.5). Cultures were maintained in $100 \mathrm{ml}$ Erlenmeyer flasks maintaining a working volume of $10 \%$. The $\mathrm{pH}$ of the medium was adjusted to 7.0. The culture was grown in at $50{ }^{\circ} \mathrm{C}$ for $18 \mathrm{~h}$ maintaining an agitation rate of $200 \mathrm{rpm}$.

\subsection{Enzyme assay}

For performing the amylase assay, $50 \mu \mathrm{l}$ of soluble starch $(1 \% \mathrm{w} / \mathrm{v})$ solution made in phosphate buffer $(50 \mathrm{mM}, \mathrm{pH} 6)$ was equilibrated at $50{ }^{\circ} \mathrm{C}$ for $5 \mathrm{~min}$. Analyte samples $(50 \mu \mathrm{l})$ were added followed by incubation for $5 \mathrm{~min}$. The reaction was stopped by adding $50 \mu \mathrm{l}$ of 3,5dinitrosalicylic acid reagent, transfer to a boiling water bath, for $10 \mathrm{~min}$, and subsequent dilution with $1 \mathrm{ml}$ distilled water. Sample absorbance was measured at $546 \mathrm{~nm}$ (Miller, 1959). Glucose was used as standard. One unit of enzyme was defined as the amount of enzyme required to release $1 \mu \mathrm{mol}$ of reducing sugar equivalent from soluble starch in one min under assay conditions. Specific activity was expressed in $\mathrm{U} / \mathrm{mg}$ of protein. Protein estimation was carried out by the Bradford method using BSA as standard (Bradford, 1976).

\subsection{Preparation of BSG hydrolysate}

BSG hydrolysate was prepared by the protocol described by Ravindran et al. (2018b). Briefly, dried, lipid-free BSG was subjected to microwave-assisted alkali pre-treatment to remove recalcitrance. Microwave assisted pre-treatment was conducted by subjecting $1 \%(\mathrm{w} / \mathrm{v})$ BSG in $0.5 \% \mathrm{NaOH}(\mathrm{w} / \mathrm{v})$ solution in a stoppered flask and subjected to microwave radiation (Sharp/R-269 KM, Sharp Electronics Ltd., Manchester, UK) at a power setting of $400 \mathrm{~W}$ for 60 s. The pre-treated BSG was then hydrolysed enzymatically following an optimized protocol (biomass loading $(1 \mathrm{~g} / 10 \mathrm{ml})$, cellulase $(158.76 \mu \mathrm{l} / 10 \mathrm{ml})$, hemicellulase (153.3 $\mu \mathrm{l} / 10 \mathrm{ml}), \mathrm{pH}(5.4)$ and an incubation time $(120 \mathrm{~h})$ ) (Ravindran et al., 2018a, 2018b). The hydrolysate obtained was then centrifuged at $10,000 \mathrm{rpm}$ for $30 \mathrm{~min}$., followed by filtration using a $0.45 \mu \mathrm{m}$ filter to remove any particulate matter. The individual sugars in the hydrolysate were measured employing Alliance HPLC (Waters, e2695 Separation module) using a Rezex ROA-Organic acid $\mathrm{H}+(8 \%)$ column, $\left(350 \times 7.8 \mathrm{~mm}\right.$; Phenomenex, UK) with $5.0 \mathrm{mM} \mathrm{H}_{2} \mathrm{SO}_{4}$ as the mobile phase at $65{ }^{\circ} \mathrm{C}$, maintaining a flow rate of $0.6 \mathrm{ml} / \mathrm{min}$. Reducing sugar was measured by the method described by Miller (1959).

\subsection{Media optimization for amylase production}

A response surface methodology design was created to optimize the media composition for production of amylase. A central composite design (CCD) was implemented to estimate the regression parameters to fit a second-degree polynomial regression model for a given response. The polynomial calculated the relationship between estimated response $\mathrm{Y}$ and all the independent variables involved, $\mathrm{X}_{\mathrm{i}}$ (starch, peptone, $\mathrm{KCl} \cdot 4$ $\mathrm{H}_{2} \mathrm{O}, \mathrm{MgSO}_{4} \cdot 7 \mathrm{H}_{2} \mathrm{O}$ and hydrolysate). Meanwhile, $\beta$ represented the regressors associated with the model. The regressors viz. model constant $\left(\beta_{\mathrm{o}}\right)$, linear coefficient $\left(\beta_{\mathrm{i}}\right)$, quadratic coefficients $\left(\beta_{\mathrm{ii}}\right)$ and cross- 
product coefficients $\left(\beta_{\mathrm{ij}}\right)$ determined the significance of linear, quadratic and interactive effects between factors (Eq. (1)).

$y=\beta_{0}+\sum_{i=1}^{5} \beta_{i} X_{i}+\sum_{i=1}^{5} \sum_{j=1}^{5} \beta_{i j} X_{i} X_{j}+\sum_{i=1}^{5} \beta_{i i} X_{i}^{2}$

The significance of each factor considered in the study was determined by analysis of variance, where $P$ values were calculated. Any factor with $\mathrm{P}<0.05$ was considered statistically significant. All statistical analyses were carried out using Statgraphics Centurion XV software version 15.1.02 (StatPoint Technologies Inc. Warrenton, VA, USA). Different level of peptone, starch, $\mathrm{KCl} \cdot 4 \mathrm{H} 2 \mathrm{O}$ and $\mathrm{MgSO} 4 \cdot 7 \mathrm{H} 2 \mathrm{O}$ and BSG hydrolysate were the media components used in this study. Fermentation experiments were conducted at $50{ }^{\circ} \mathrm{C}$ for $36 \mathrm{~h}$ at $220 \mathrm{rpm}$ while maintaining a working volume of $20 \%$. The hydrolysate was autoclaved separately from the rest of the reaction mixture and was then aseptically added to prevent the Milliard reaction (Mottram et al., 2002).

\subsection{Control experiment}

Control experiments for amylase production by B. stearothermophilus were set up according to protocols devised by Al-Qodah (2006). Fermentation was conducted in $250 \mathrm{ml}$ Erlenmeyer flask maintaining a reaction volume of $20 \%$. The flasks were incubated at $55^{\circ} \mathrm{C}$ in a shaking incubator rotating at $220 \mathrm{rpm}$ for $36 \mathrm{~h}$. The culture supernatant was collected by centrifugation at $12,000 \mathrm{rpm}$ for $30 \mathrm{mins}$ at $4{ }^{\circ} \mathrm{C}$ and used for further analysis.

\subsection{Dry cell weight analysis}

The effect of fermentation medium supplemented by BSG hydrolysate on the production of biomass was studied by conducting dry cell weight analysis. Briefly, temperature-resistant plastic universal bottles ( $20 \mathrm{ml}$ capacity) was dried over in a hot air oven at $105^{\circ} \mathrm{C}$ with the lids separately retained. These were then carefully removed from the oven and placed in a desiccator jar. Once the universals were cooled they were weighed and the weights were recorded. Next, $15 \mathrm{ml}$ aliquot of each test and control fermentation cultures were decanted into the preweighed universal. The universals were then centrifuged at 15,000 rpm for $30 \mathrm{~min}$ at $4^{\circ} \mathrm{C}$ to pellet the cells. The supernatant was carefully transferred into sterile bottles and stored for further experiments. Meanwhile, the universals with cell pellets were dried at $105^{\circ} \mathrm{C}$ in a hot air oven for $24 \mathrm{~h}$ and then placed in a desiccator jar. Finally, each universal was re-weighed, and the dry cell weight was calculated in $\mathrm{mg} / \mathrm{ml}$.

\subsection{Purification of $\alpha$-amylase}

Cell removal was performed by centrifugation at $15,000 \mathrm{rpm}$ for $30 \mathrm{~min}$ at $4^{\circ} \mathrm{C}$. The cell free supernatant was then subjected to precipitation using ammonium sulphate $(60 \%(\mathrm{w} / \mathrm{v}))$. The precipitate was re-suspended in $10 \mathrm{ml}$ of $0.1 \mathrm{M}$ sodium phosphate buffer ( $\mathrm{pH} 7.0$ ). This was followed by salt removal-buffer exchange by diafiltration $(10 \mathrm{kDa}$ MWCO, Amicon Corporation, Lexington, Mass., U.S.A.). Anion exchange chromatography was performed following the protocol devised by Chakraborty et al. (2000) with slight modifications. A DEAE-Sepharose Fast Flow column $(2.6 \mathrm{~cm} \times 50 \mathrm{~cm})$ was used for this purpose. The column was equilibrated with $20 \mathrm{mM}$ Tris- $\mathrm{HCl}$ buffer ( $\mathrm{pH} 8.0$ ) before loading the sample. Elution was performed using $20 \mathrm{mM}$ tris- $\mathrm{HCl}$ containing $0.5 \mathrm{M} \mathrm{NaCl}(\mathrm{pH} \mathrm{8.0)}$ ) and $2 \mathrm{ml}$ fractions were collected at $15 \mathrm{ml} / \mathrm{h}$ and measured at $280 \mathrm{~nm}$. The active fractions were pooled and concentrated by ultrafiltration ( $10 \mathrm{kDa}$ cut-off).

\subsection{Determination of kinetic constants for starch}

The Michaelis constant $\left(\mathrm{K}_{\mathrm{m}}\right)$ and maximum reaction velocity $\left(\mathrm{V}_{\max }\right)$ of purified amylase for starch was determined by using Lineweaver and Burk plot (Lineweaver and Burk, 1934).

\subsection{Effect of surfactants and detergents on enzyme activity}

The stability of thermostable $\alpha$-amylase was studied by incubating it for $1 \mathrm{~h}$ at $50^{\circ} \mathrm{C}$ in different surfactants such as Tween-20, Tween-80 and SDS. This was followed by the measurement of residual activity following standard assay protocols. Furthermore, the enzyme was tested for laundry applications by assessing its stability in solid and liquid detergent brands. Four detergents brands viz. Ariel (Proctor and Gamble), Daz (Proctor and Gamble), Fairy (Proctor and Gamble) and Persil (Henkel, Unilever) were chosen for this purpose. The solid detergents were diluted in tap water to obtain a final concentration of $7 \%$. Meanwhile, the liquid detergents were diluted 100 -fold to simulate washing conditions. The detergents were then incubated at $65^{\circ} \mathrm{C}$ for $1 \mathrm{~h}$ to inactivate endogenous proteases present in it. Crude enzyme containing $200 \mathrm{U} / \mathrm{ml}$ was incubated with the detergents for $1 \mathrm{~h}$ at 40,50 and $60{ }^{\circ} \mathrm{C}$ and the residual activity was determined. Enzyme activity devoid of detergents incubated at similar conditions was considered as $100 \%$.

\subsection{Screening of pathogens for biofilm production capacity}

Pathogenic bacterial strains Staphylococcus aureus NCTC 1803, S. aureus ATCC 25923 and Pseudomonas aeruginosa ATCC 27853 were obtained from the DIT microbiology repository. The strains were revived by growing them over night in LB broth at $37^{\circ} \mathrm{C}$ for $18 \mathrm{~h}$. Each strain was then plated on brain-heart infusion agar supplemented with $3.6 \%$ sucrose and $0.08 \%$ Congo Red dye. The plates were incubated for $48 \mathrm{~h}$ at $37^{\circ} \mathrm{C}$ following which they were inspected for biofilm formation.

\subsection{Biofilm formation assay}

The effect of thermostable $\alpha$-amylase on the growth of pathogenic organisms and its capacity to inhibit biofilm formation were determined by spectrophotometric assays. The assay was conducted following the protocol reported by Vaikundamoorthy et al. (2018) with slight modifications. The crude $\alpha$-amylase enzymes were taken in different volumes ranging from 50,100, 150, 200 and $250 \mu \mathrm{l} / \mathrm{ml}$ were suspended in LB broth ( $\mathrm{pH} 7.0)$ containing bacterial suspension at $10^{6} \mathrm{CFU} / \mathrm{ml}$. Meanwhile, the efficacy of commercial amylase as an antibiofilm agent was also assessed. Different volumes of the commercial amylase were added to the bacterial suspensions ranging from 20 to $100 \mu \mathrm{l} / \mathrm{ml}$ of LB broth and the its effect of biofilm production was determined.

The biofilm assay was conducted in 96-well microtiter plates. The wells were filled with $100 \mu \mathrm{l}$ of LB broth following which the microtiter plate was then incubated at $37^{\circ} \mathrm{C}$ for $24 \mathrm{~h}$ for biofilm formation. Meanwhile, wells with LB broth and without enzymes were used as control. Following incubation, the culture was discarded, and the plates were washed repeatedly with distilled water. The wells were then stained with $125 \mu \mathrm{l}$ of $0.1 \%$ crystal violet and incubated at room temperature for $15 \mathrm{~min}$., after which the contents of the wells were discarded. For quantification purposes, $125 \mu \mathrm{l}$ of acetic acid (30\%) was added to each well and incubated at room temperature for $15 \mathrm{~min}$. The contents were then transferred to a separate 96-well microtiter plate and absorbance was measured at $550 \mathrm{~nm}$. Acetic acid was used as a blank. Biofilm inhibitory concentration was defined as the lowest concentration that produced significant reduction in biofilm formation (spectrophotometric equivalent) when compared to control wells. 


\section{Results and discussion}

\subsection{Utilisation of BSG hydrolysate as a media component for amylase production}

In this study, BSG hydrolysate which was rich in fermentable sugars was tested as a media component for the production of thermostable $\alpha$ amylase using B. stearothermophilus LZT020. Sugar composition analysis of the BSG substrate indicated glucose $(2.5 \mathrm{mg} / \mathrm{ml})$, xylose $(2.1 \mathrm{mg} / \mathrm{ml})$, mannose $(1.3 \mathrm{mg} / \mathrm{ml})$, arabinose $(1.0 \mathrm{mg} / \mathrm{ml})$ and galactose $(4.1 \mathrm{mg}$ / $\mathrm{ml}$ ), and total reducing sugar content was $20 \mathrm{mg} / \mathrm{ml}$. The optimal concentration of each media component was investigated by response surface methodology. Peptone, starch, $\mathrm{KCl} \cdot 4 \mathrm{H}_{2} \mathrm{O}$ and $\mathrm{MgSO}_{4} \cdot 7 \mathrm{H}_{2} \mathrm{O}$ and BSG hydrolysate were the media components considered in this study. The concentrations of BSG hydrolysate, peptone, starch, $\mathrm{KCl}$ and $\mathrm{MgSO}_{4}$ were varied according to the experimental strategy. The model generated a regression equation which explained the relationship that existed between the amylase yield and all the parameters considered in the experimental design which is provided below:

$$
\begin{aligned}
\text { Amylase activity }(\mathrm{U} / \mathrm{ml})= & 13.3337+475.416 \times \mathrm{X}_{1}-31.1953 \times \mathrm{X}_{2} \\
& +5923.18 \times \mathrm{X}_{3}-5094.32 \times \mathrm{X}_{4}+725.692 \times \mathrm{X}_{5} \\
& -1476.61 \times \mathrm{X}_{1}^{2}-85.0465 \times \mathrm{X}_{1} \times \mathrm{X}_{2} \\
& +2461.56 \times \mathrm{X}_{1} \times \mathrm{X}_{3}+5161.56 \times \mathrm{X}_{1} \times \mathrm{X}_{4} \\
& +494.906 \times \mathrm{X}_{1} \times \mathrm{X}_{5}-86.6518 \times \mathrm{X}_{2}^{2} \\
& +2350.47 \times \mathrm{X}_{2} \times \mathrm{X}_{3}+3200.46 \times \mathrm{X}_{2} \times \mathrm{X}_{4} \\
& -18.078 \times \mathrm{X}_{2} \times \mathrm{X}_{5}-147161 . \times \mathrm{X}_{3}^{2} \\
& +50884.4 \times \mathrm{X}_{3} \times \mathrm{X}_{4}-7499.06 \times \mathrm{X}_{3} \times \mathrm{X}_{5} \\
& -58660.6 \times \mathrm{X}_{4}^{2}+9225.94 \times \mathrm{X}_{4} \times \mathrm{X}_{5} \\
& -1761.61 \times \mathrm{X}_{5}^{2}
\end{aligned}
$$

where $\mathrm{X}_{1}, \mathrm{X}_{2}, \mathrm{X}_{3}, \mathrm{X}_{4}$ and $\mathrm{X}_{5}$ represents starch, peptone, $\mathrm{KCl}, \mathrm{MgSO}_{4}$ and BSG hydrolysate, respectively. Analysis of variance was conducted to determine the significance of the all the parameters considered in the model. From the analysis of variance with respect to parameters, combined effects and the P-value assigned by the model to each of them considering a confidence interval spanning from 0 to $95 \%$. Any parameter or combined effect which was assigned P-value $<0.05 \%$ was considered to be significant in terms of influence on amylase activity.

The coefficient of determination $\left(\mathrm{R}^{2}\right)$ was calculated to determine if the model adequately fitted the data. The closeness of $R^{2}$ to 1.0 is an indication of the strength of the model and how well it can predict a response. Statistical analysis helps in the determination of parameters that generate signals that are larger than the noise. In a model where the sample size is not very large in comparison with the number of parameters, the adjusted $R^{2}$ corrects the $R^{2}$ value. A disproportionate number of terms with respect to the sample size manifests in a noticeably smaller adj- $\mathrm{R}^{2}$ value compared to the $\mathrm{R}^{2}$ value. The model predicted an $\mathrm{R}^{2}$ value of $99.37 \%$ and an adj- $\mathrm{R}^{2}$ value of $97.97 \%$ indicating a good agreement between experimental and predicted values of amylase activity.

All the factors considered in the model were found to have a significant effect and enhanced the production of amylase activity. Inorganic salts like $\mathrm{MgSO}_{4}$ and $\mathrm{KCl}$ have been reported to have a positive influence on $\alpha$-amylase production by $B$. stearothermophilus (Srivastava and Baruah, 1986). Furthermore, starch and other polysaccharides positively influences $\alpha$-amylase production by Bacillus sp. (Gangadharan et al., 2008). The P-values also indicated that some of the interactive effects of the media components were significant with respect to $\alpha$-amylase production.

The interactive effects of all the media components on the amylase activity was analyzed by generating 3-D response surface plots (Fig. 1). In all the cases the lower concentration of BSG hydrolysate tended to enhance amylase activity. Maximum amylase activity was achieved at a
BSG hydrolysate concentration range of 0.2 to $0.24 \%$. Any increase in hydrolysate concentration in the media beyond this range was found to be detrimental to enzyme activity. A higher hydrolysate concentration was found to be inhibitory for amylase production. This might be due to catabolite repression due to the presence of glucose in the hydrolysate (Ravindran et al., 2018a, 2018b). In a recent study, Ouattara et al. (2017) had reported incidences of catabolite repression due to the presence of glucose in the fermentation media when Bacillus sp. was used as the enzyme producer. Although a higher concentration of glucose can result in catabolite repression, the presence of this monosaccharide in the fermentation medium enhances the growth of the bacteria. In fact, lower concentrations of maltose and glucose have been reported to enhance amylase activity in B. stearothermophilus (Rahmati et al., 2017). A higher biomass production does not necessarily have to translate into similar enzyme production kinetics. Simair et al. (2017) conducted an extensive study to determine the best carbon and nitrogen sources for Bacillus sp. BCC 01-50 amylase. Although there was no significant difference in biomass formation glucose augmented medium compared to that containing starch, the latter resulted in higher amylase activity.

To study the effects of BSG hydrolysate on biomass formation dry cell weight studies were conducted. Consequently, a $22 \%$ increase in biomass was observed in the experimental trial when compared to control. These all point to the fact that low concentrations of BSG hydrolysate is favourable for cell biomass formation and $\alpha$-amylase production. An increase in peptone content also positively influences the amylase activity. Rajagopalan and Krishnan (2008) had reported similar findings in a study involving the effects of peptone concentration in media on the production of $\alpha$-amylase by Bacillus subtilis KCC103.

The RSM experimental design generated optimized levels for every factor upon analyzing the observed amylase activity after each trial. Accordingly, the optimized values for each media component was as follows: starch $0.2 \%(\mathrm{w} / \mathrm{v})$, peptone $0.2 \%(\mathrm{w} / \mathrm{v}), \mathrm{KCl} \cdot 4 \mathrm{H}_{2} \mathrm{O} 0.02 \%(\mathrm{w} /$ v), $\mathrm{MgSO}_{4} \cdot 7 \mathrm{H}_{2} \mathrm{O} 0.01 \%(\mathrm{w} / \mathrm{v})$ and hydrolysate $0.22 \%(\mathrm{v} / \mathrm{v})$. The model predicted an enzyme activity of $203.3 \mathrm{U} / \mathrm{ml}$ on testing the optimized conditions. Validation experiments following optimized media composition resulted in $198.09 \mathrm{U} / \mathrm{ml}$ of amylase activity. Minimal disparity between predicted and observed values $(<5 \%)$ confirmed that the model was valid and also indicated that it was adequate enough to predict the optimum values for variables considered for amylase production. Furthermore, the amylase yield obtained after optimizing the media formulation was 1.3-fold higher than that observed after control fermentation $(152.3 \mathrm{U} / \mathrm{ml})$.

\subsection{Purification of thermostable B. stearothermophilus amylase}

Enzymes are commonly purified by a multi-step process. These steps may be specific or non-specific depending upon the purification strategy adopted. Increasing the number of steps in protein purification strategy can result in a low final yield (Bajpai, 2014). Ion exchange chromatography is a common technique used for the purification of $\alpha$ amylase. In this study, a three-step strategy was adopted to purify the thermostable $\alpha$-amylase. The summary of the purification stages has been provided in Table 1 . The crude enzyme which exhibited a total activity of $9152 \mathrm{U}$ and specific activity of $34.63 \mathrm{U} / \mathrm{mg}$ was subjected to ammonium sulphate precipitation $(65 \% \mathrm{w} / \mathrm{v})$ at $4{ }^{\circ} \mathrm{C}$. This step resulted in a purification of 1.24 -fold and theoretical yield of $76 \%$. This was followed by an ultrafiltration/diafiltration step which led to an increase in purification fold by 12.44 -fold. The final purification strategy involved ion exchange chromatography where the concentrate was loaded on to DEAE-Sepharose Fast Flow column and eluted using $0.5 \mathrm{M}$ $\mathrm{NaCl}$ via isocratic mode after removal of unwanted proteins. The active fractions were collected and concentrated by diafiltration.

The last stage of purification resulted in the final enzyme preparation achieving 13.09-fold purification and a theoretical yield of $25.1 \%$. As shown in Fig. 2, a single, salt-eluted peak $\left(\mathrm{A}_{280}\right)$ was obtained in ion- 


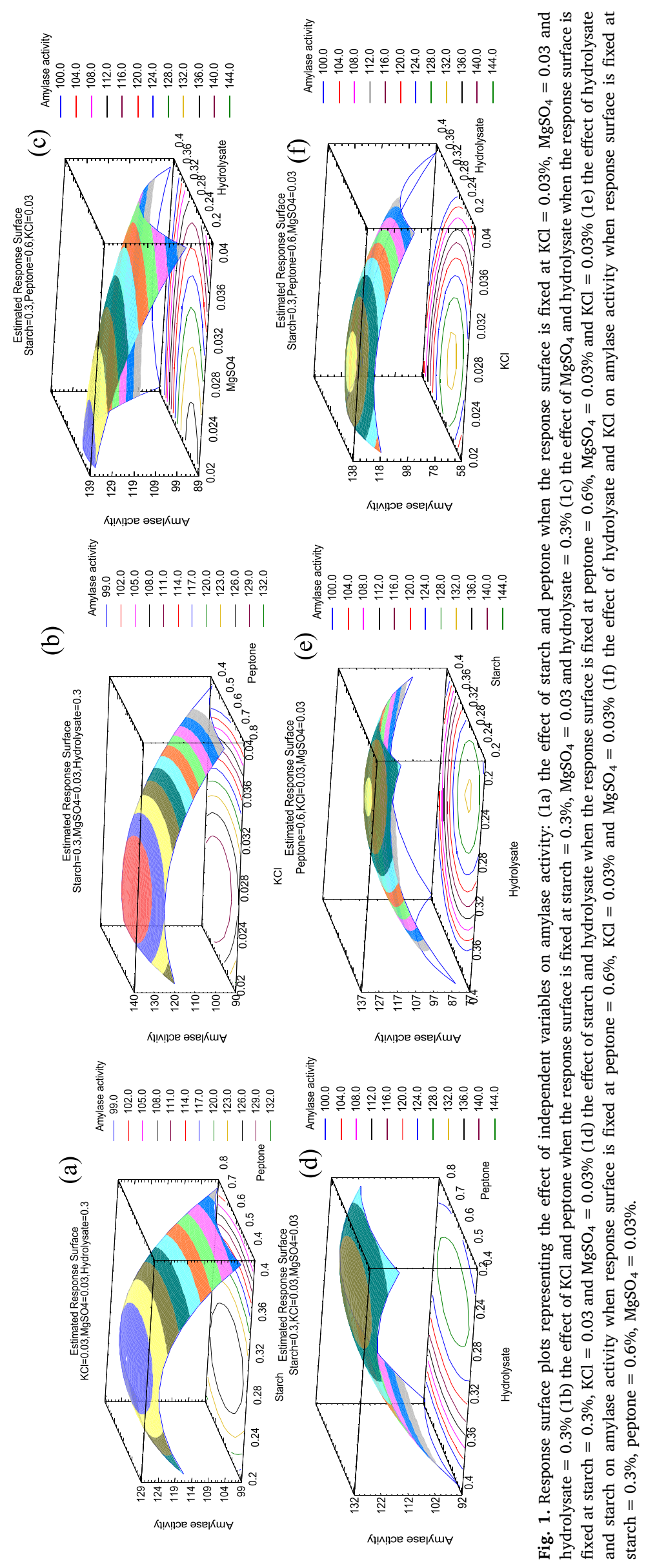


Table 1

Purification of $\alpha$-amylase from $B$. stearothermophilus.

\begin{tabular}{|c|c|c|c|c|c|}
\hline Step & Total activity (U) & Total protein (mg) & Specific activity (U/mg) & Purity (fold) & Theoretical yield (\%) \\
\hline Cell Supernatant & 9152 & 264 & 34.63 & 1.00 & 100 \\
\hline Ammonium sulphate precipitate & 6956 & 161 & 43.15 & 1.24 & 76.0 \\
\hline Ultra/Diafiltration & 5508 & 13 & 431.13 & 12.44 & 58.0 \\
\hline DEAE Sepharose Fast Flow & 2297 & 5 & 453.45 & 13.09 & 25.1 \\
\hline
\end{tabular}

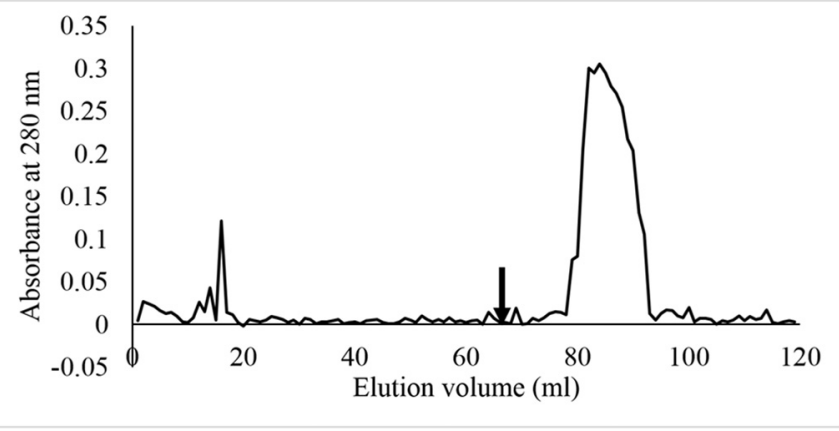

Fig. 2. Elution profile of $\alpha$-amylase from DEAE Sepharose Fast Flow.

exchange chromatography. The theoretical yield and purification folds can be comparable with earlier published studies. Chakraborty et al. (2000) in studies involving B. stearothermophilus for amylase production had reported a yield of $56 \%$ and purification fold of 6.7. Similarly, Fincan and Enez (2014) reported a purification fold of 65 and yield of $46 \%$ employing a four step purification strategy that involved size exclusion chromatography (Sephadex G-100) followed by ion exchange chromatography employing DEAE cellulose. The three-stage purification strategy adopted in this study for thermostable $\alpha$-amylase enabled the authors to perform biochemical characterization to determine the optimum $\mathrm{pH}$ and temperature for enzyme activity. Furthermore, the purification fold and yield of the $\alpha$-amylase was high with less number of purification stages. This purification procedure can be easily adopted for large-scale purification.

The molecular weight of denatured thermostable $\alpha$-amylase was determined by relative mobility of standard proteins on SDS-PAGE. The relative molecular mass of the enzyme was estimated via $10 \%$ SDSPAGE and appeared to be $64 \mathrm{kDa}$ (Fig. 3). The enzyme appeared as a single protein band suggesting that it was a homogenous monomer with a single polypeptide chain. This was in agreement to reports published

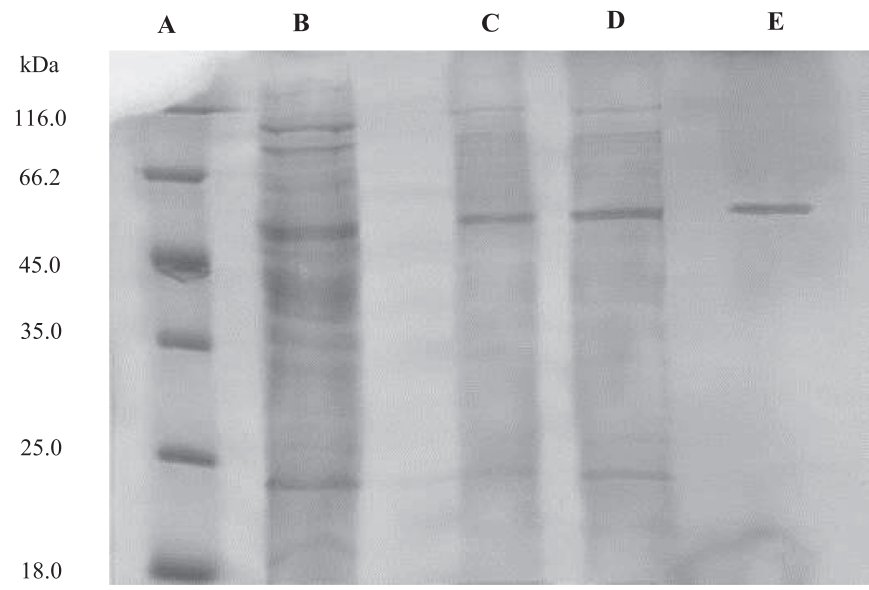

Fig. 3. SDS-PAGE illustrates different stages of purification: (A) molecular size markers (B) Cell free supernatant (crude enzyme), (C) enzyme after ammonium sulphate precipitation (D) Enzyme after ultrafiltration/diafiltraion (E) enzyme after DEAE-Sepharose Fast Flow Chromatography. elsewhere. For example, Fincan and Enez (2014) conducted an extensive study that purified and characterised $\alpha$-amylase produced by Geobacillus stearothermophilus where molecular weight of thermostable amylase was found to be $63 \mathrm{kDa}$.

\subsection{Effect of $\mathrm{pH}$ and temperature on enzyme activity}

The optimum $\mathrm{pH}$ and $\mathrm{pH}$ stability of an enzyme is a deciding factor in determining its commercial applicability. The $\alpha$-amylase produced by $B$. stearothermophilus have been reported to be exhibit higher activity in the alkaline $\mathrm{pH}$ range (Fincan and Enez, 2014). The stability of the enzyme was tested in different $\mathrm{pH}$ conditions ranging from 4 to 12 . The $\alpha$-amylase was found to be least active at an acidic $\mathrm{pH}$ range. This might have been due to the inactivation of the enzyme at a lower $\mathrm{pH}$. As the $\mathrm{pH}$ was increased, the enzyme exhibited higher activity until the neutral $\mathrm{pH}$ range, Optimum $\mathrm{pH}$ for maximum activity was found to be within the $\mathrm{pH}$ range of 7-8 (Fig. 4a). As the study progressed into the alkaline $\mathrm{pH}$ range, the activity started diminishing slightly. Even at a $\mathrm{pH}$ as alkaline as 12 , the $\alpha$-amylase exhibited almost $50 \%$ of its original activity. Amylases that are active at an alkaline $\mathrm{pH}$ are in high demand due to their potential applications in the textile industry and as

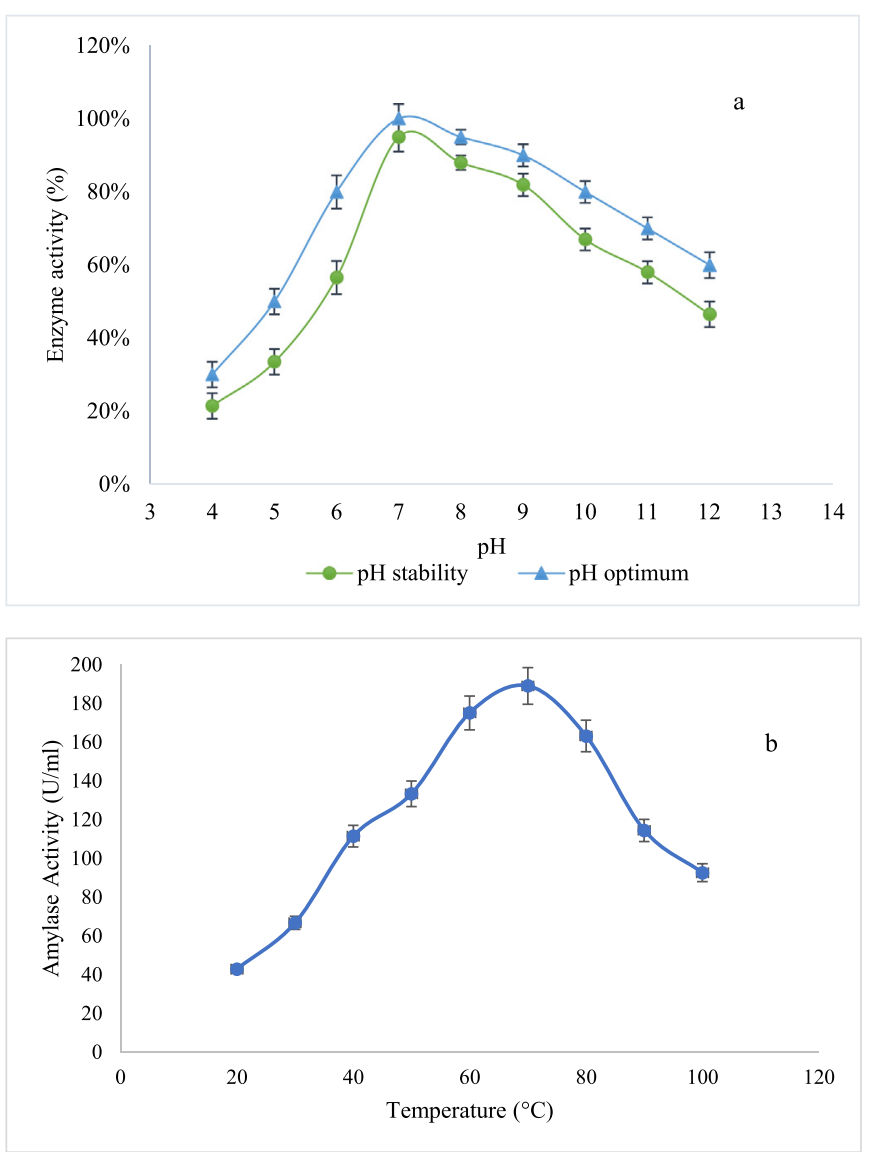

Fig. 4. a) Effect of $\mathrm{pH}$ on the activity and stability of $\alpha$-amylase b) effect of temperature on the activity of $\alpha$-amylase. 
ingredients for detergent production (Lu et al., 2016).

The activity of the $B$. stearothermophilus amylase was assessed at various temperatures ranging from $20^{\circ} \mathrm{C}$ to $100{ }^{\circ} \mathrm{C}$. The optimum temperature for maximum enzyme activity was found to be between $60^{\circ} \mathrm{C}$ to $70^{\circ} \mathrm{C}$. The enzyme was highly thermostable and exhibited activity at temperatures as high as $100^{\circ} \mathrm{C}$. Amylases derived from $B$. stearothermophilus have been reported to exhibit thermostability. Li et al. (2016) conducted a study where wild strains as well as mutants of B. stearothermophilus amylase were studied. They reported that for all the strains studied, the optimum temperature for $\alpha$-amylase activity was found to be $70{ }^{\circ} \mathrm{C}$. However, the enzyme retained $80 \%$ of its activity at temperatures of $40{ }^{\circ} \mathrm{C}$ and above. These observations rightly point out that $B$. stearothermophilus amylase may have applications in industries such as traditional brewing and other food processing applications such as pasteurization where higher temperatures can render mesophilic amylases useless.

\subsection{Determination of kinetic constants}

The $\mathrm{K}_{\mathrm{m}}$ and $\mathrm{V}_{\mathrm{max}}$ for thermostable amylase was calculated for starch using Lineweaver-Burk plot. A value of $4.01 \times 10^{3} \mu \mathrm{g}$ starch $/ \mathrm{ml}$ and $5.98 \times 10^{3} \mu \mathrm{g} / \mathrm{ml} \cdot \mathrm{min}$ was obtained for $\mathrm{K}_{\mathrm{m}}$ and $\mathrm{V}_{\max }$ respectively.

\subsection{Effect of surfactants and detergents on enzyme activity}

The stability of the thermostable amylase obtained from B. stearothermophilus for laundry applications was tested by incubating it in surfactants and commercial detergents. Table 2 represents the residual activity of the enzymes obtained after incubating in common surfactants for $1 \mathrm{~h}$. The amylase was able to retain high activity and moderate activity after incubation in Tween-20 and Tween-80 respectively. However, incubation in SDS resulted considerable decrease in amylase activity indicating substantial denaturation of the enzyme.

On the other hand, $\alpha$-amylase was considerably stable in solid as well as liquid detergents (Fig. 5). The enzyme retained close to $100 \%$ activity in all the solid detergents tested. Measurement of residual activity after incubation in diluted solid detergent solutions revealed a trend where the activity decreased with increase in incubation temperature. Highest residual activities were observed in Ariel and Daz when incubated at $40^{\circ} \mathrm{C}$. Structural denaturation of the enzyme due to higher temperature might be the reason behind this observation. $B$. stearothermophilus amylase was not as effective in the presence of liquid detergents. As was with solid detergents, as incubation temperature increased the residual activity was detrimentally affected. A higher activity of the enzyme in solid detergents as opposed to liquid detergents can be explained by the nature of the latter where the presence of water amplifies the deleterious effects of surfactants (Khemakhem et al., 2009).

\subsection{Antibiofilm activity of $\alpha$-amylase and determination of inhibitory concentration}

Antimicrobial agents ineffective against biofilm producing bacteria due to their ability to produce exopolysaccharides (EPS). This forms a barrier around the bacterial cell protecting it within the biofilm. Enzymes such as proteases and lysozyme have been proven to be

Table 2

Effect of surfactants on the activity of $B$. stearothermophilus.

\begin{tabular}{lcc}
\hline Surfactants & Concentration (\%) & Residual activity (\%) \\
\hline None & - & 100 \\
Tween 20 & 10 & 95.5 \\
Tween 80 & 10 & 74.3 \\
SDS & 10 & 55 \\
\hline
\end{tabular}

effective antibiofilm agents (Mirsada et al., 2018; Vaikundamoorthy et al., 2018). Carbohydrate degrading enzymes such as cellulases and amylases along with alginate lyase have been shown to reduce biofilm activity in Pseudomonas strains. This polysaccharide structure is necessary for the bacterial cell for pellicle formation (Alkawas et al., 2006). Additionally, polysaccharide intercellular adhesin (PIA), extracellular-DNA, proteins, and amyloid fibrils form the extracellular polymeric structures of staphylococcal biofilm. Therefore, in this study, three strains viz. S. aureus NCTC 1803, S. aureus ATCC 25923 and $P$. aeruginosa ATCC 27835 were screened for biofilm production capacity. Black colonies with crystalline consistency was an indication of biofilm formation (Lee et al., 2016). In the case of commercial amylase (specific activity $439.0 \mathrm{U} / \mathrm{mg}$ ), $20 \mu \mathrm{l}$ of the amylase was able to inhibit biofilm production by all the three strains (Fig. 6a). The crude enzyme (specific activity $36.63 \mathrm{U} / \mathrm{mg}$ ) was able to achieve considerable disruption in biofilm formation in all the pathogenic organisms tested. The BIC for crude enzyme varied among all the bacterial strains tested (Fig. 6b). The BIC for S. aureus NCTC 1803 and S. aureus ATCC 25923 was found to be $150 \mu \mathrm{l}(198.09 \mathrm{U} / \mathrm{ml})$. Meanwhile the BIC for P. aeruginosa ATCC 27853 was $100 \mu$ l. Thereafter, increasing the concentrations of the amylase led to the decrease in biofilm inhibition. This trend was observed in both crude amylase and commercial amylase trails. Employing crude amylase resulted in inhibiting biofilm formation of the all the strains tested by $62 \%, 55 \%$ and $50 \%$ respectively. A similar observation was reported by Kalpana et al. (2012) that involved crude, purified and commercial amylase derived from Bacillus subtilis S8-18 as an antibiofilm forming agent against pathogenic bacterial strains.

Exopolysaccharides provide strength to the bacterial cell wall while preventing the entry of antimicrobial agents in to cells (Czaczyk and Myszka, 2007). Circumventing this problem calls for novel solutions. $\alpha$ amylase have been widely studied as a potential anti-biofilm agent by several researchers. Craigen et al. (2011) found that $\alpha$-amylases from four different sources viz. Bacillus, Aspergillus, sweet potato and saliva was effective against biofilm producing capacity of Staphylococcus aureus. Other studies have reported that proteases are better at preventing biofilm formation and antimicrobial activity compared to $\alpha$ amylases (Mitrofanova et al., 2017; Molobela et al., 2010). Some studies report the use of an antimicrobial enzyme cocktail including proteases, lysozyme, oxidative enzymes, amylases etc. to prevent or remove biofilm formation. However, the presence of protease can lead to the degradation of other enzymes leading to partial removal of biofilm (Kalpana et al., 2012). Hence this study was solely focused on the effect of thermostable B. stearothermophilus $\alpha$-amylase on biofilm formation.

\section{Conclusion}

In this study, for the first time BSG hydrolysate was used to successfully formulate media for the production of thermostable $\alpha$-amylase by $B$. stearothermophilus. The presence of hydrolysate in small quantities enhanced the growth and enzyme yield of $B$. stearothermophilus. This resulted in an increase of enzyme yield by 1.3 -fold. The enzyme produced was purified by three-step purification strategy. This resulted in a 13.09 -fold purification with a yield of $25 \%$. Produced $\alpha$-amylase showed antibiofilm activity against number of pathogens and also found to be considerably stable in solid and liquid detergents and can be used in laundry applications.

\section{Conflict of interest statement}

The authors declare that they have no conflict of interest.

\section{Acknowledgements}

Authors would like to acknowledge the funding from Dublin Institute of Technology (DIT), Dublin, Ireland under the Fiosraigh Scholarship programme, 2014. 


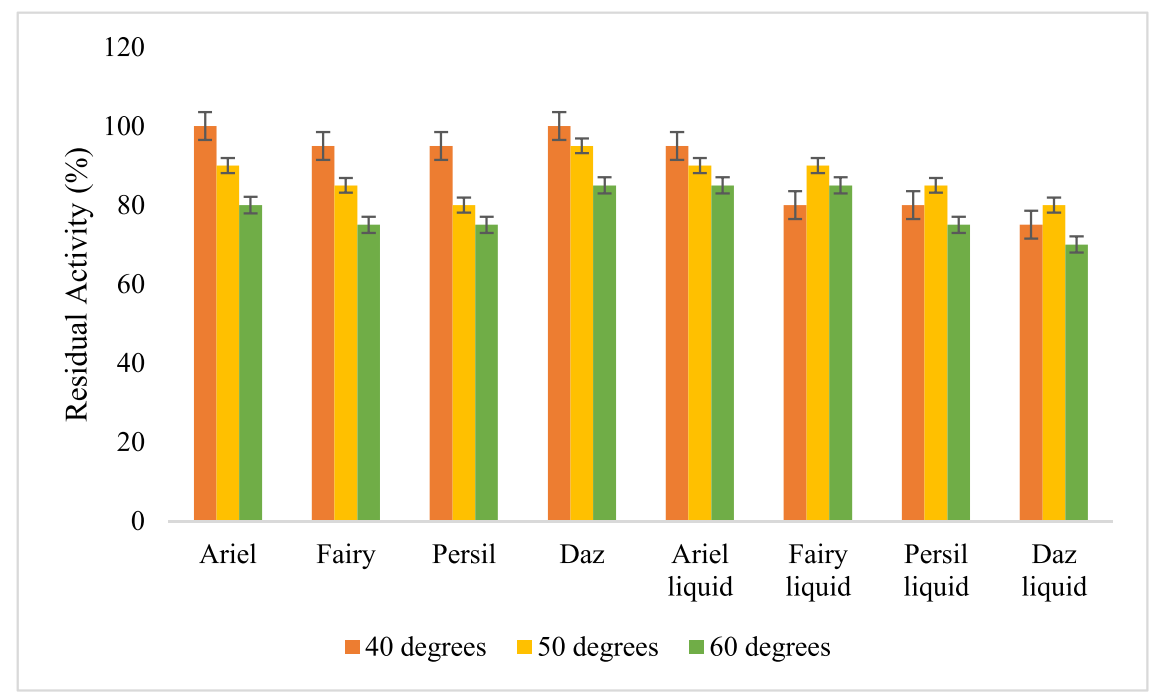

Fig. 5. Residual activity of thermostable $\alpha$-amylase in the presence of various commercial solid and liquid detergents.

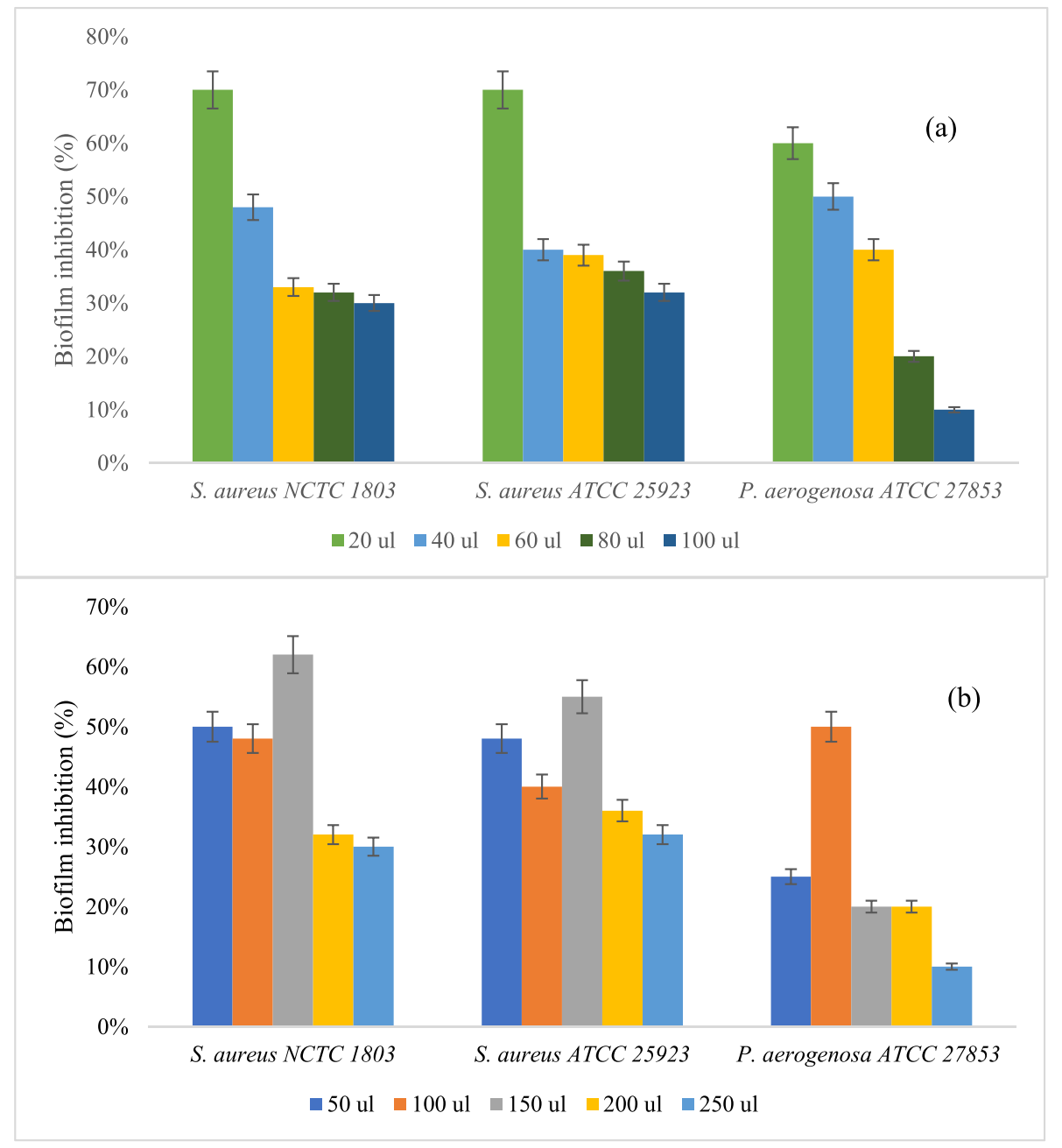

Fig. 6. Quantitative determination of BIC for commercial $\alpha$-amylase enzyme (a) and (b) crude $\alpha$-amylase from B. stearothermophilus.

\section{Appendix A. Supplementary data}

Supplementary data to this article can be found online at https:// doi.org/10.1016/j.biteb.2019.01.004.

\section{References}

Alkawas, M.A., Soothill, J.S., Schiller, N.L., 2006. Alginate lyase enhances antibiotic killing of mucoid Pseudomonas aeruginosa in biofilms. APMIS 114, 131-138.

Al-Qodah, Z., 2006. Production and characterization of thermostable $\alpha$-amylase by thermophilic Geobacillus stearothermophilus. Biotechnol. J. 1, 850-857. 
Association, I.B., 2016. Beer Industry in Ireland.

Bajpai, P., 2014. Chapter 6 - purification of xylanases. In: Bajpai, P. (Ed.), Xylanolytic Enzymes. Academic Press, Amsterdam, pp. 53-61.

Bradford, M.M., 1976. A rapid and sensitive method for the quantitation of microgram quantities of protein utilizing the principle of protein-dye binding. Anal. Biochem. 72, 248-254.

Chakraborty, K., Bhattacharyya, B., Sen, S., 2000. Purification and characterization of a thermostable $\alpha$-amylase from Bacillus stearothermophilus. Folia Microbiol. 45, 207-210.

Chen, J., Gai, Y., Fu, G., Zhou, W., Zhang, D., Wen, J., 2015. Enhanced extracellular production of $\alpha$-amylase in Bacillus subtilis by optimization of regulatory elements and over-expression of PrsA lipoprotein. Biotechnol. Lett. 37, 899-906.

Costerton, J.W., Stewart, P.S., Greenberg, E.P., 1999. Bacterial biofilms: a common cause of persistent infections. Sci. 284, 1318-1322.

Craigen, B., Dashiff, A., Kadouri, D.E., 2011. The use of commercially available alphaamylase compounds to inhibit and remove Staphylococcus aureus biofilms. Open Microbiol. J. 5, 21-31.

Czaczyk, K., Myszka, K., 2007. Biosynthesis of extracellular polymeric substances (EPS and its role in microbial biofilm formation. Pol. J. Environ. Stud. 16.

Fincan, S.A., Enez, B., 2014. Production, purification, and characterization of thermostable $\alpha$-amylase from thermophilic Geobacillus stearothermophilus. Starke. 66, 182-189.

Gangadharan, D., Sivaramakrishnan, S., Nampoothiri, K.M., Sukumaran, R.K., Pandey, A., 2008. Response surface methodology for the optimization of alpha amylase production by Bacillus amyloliquefaciens. Bioresour. Technol. 99, 4597-4602.

Gregori, A., Švagelj, M., Pahor, B., Berovič, M., Pohleven, F., 2008. The use of spent brewery grains for Pleurotus ostreatus cultivation and enzyme production. New Biotechnol. 25, 157-161.

Hall-Stoodley, L., Stoodley, P., 2005. Biofilm formation and dispersal and the transmis sion of human pathogens. Trends Microbiol. 13, 7-10.

Hashemi, M., Razavi, S.H., Shojaosadati, S.A., Mousavi, S.M., 2011. The potential of brewer's spent grain to improve the production of $\alpha$-amylase by Bacillus sp. KR-8104 in submerged fermentation system. New Biotechnol. 28, 165-172.

Jamal, M., Ahmad, W., Andleeb, S., Jalil, F., Imran, M., Nawaz, M.A., Hussain, T., Ali, M., Rafiq, M., Kamil, M.A., 2018. Bacterial biofilm and associated infections. J. Chin. Med. Assoc. 81, 7-11.

Kalpana, B.J., Aarthy, S., Pandian, S.K., 2012. Antibiofilm activity of $\alpha$-amylase from Bacillus subtilis S8-18 against biofilm forming human bacterial pathogens. Appl. Biochem. Biotechnol. 167, 1778-1794.

Khemakhem, B., Ali, M.B., Aghajari, N., Juy, M., Haser, R., Bejar, S., 2009. Engineering of the $\alpha$-amylase from Geobacillus stearothermophilus US100 for detergent incorporation. Biotechnol. Bioeng. 102, 380-389.

Łaba, W., Piegza, M., Kawa-Rygielska, J., 2017. Evaluation of brewer's spent grain as a substrate for production of hydrolytic enzymes by keratinolytic bacteria. J. Chem. Technol. Biotechnol. 92, 1389-1396.

Lal, N., Jyoti, J., Sachan, P., 2017. Optimization of carbon sources for the amylase production and growth of Bacillus licheniformis JAR-26 under submerged fermentation. Indian J. Biol. 4.

Lee, J.-S., Bae, Y.-M., Han, A., Lee, S.-Y., 2016. Development of Congo red broth method for the detection of biofilm-forming or slime-producing Staphylococcus sp. LWT 73, 707-714.

Li, Z., Duan, X., Wu, J., 2016. Improving the thermostability and enhancing the $\mathrm{Ca}^{2}$ binding of the maltohexaose-forming $\alpha$-amylase from Bacillus stearothermophilus. J. Biotechnol. 222, 65-72.

Lineweaver, H., Burk, D., 1934. The determination of enzyme dissociation constants. J. Am. Chem. Soc. 56, 658-666.

Lu, Z., Wang, Q., Jiang, S., Zhang, G., Ma, Y., 2016. Truncation of the unique N-terminal domain improved the thermostability and specific activity of alkaline $\alpha$-amylase Amy703. Sci. Rep. 6, 22465.

Mihailescu, R., Tafin, U.F., Corvec, S., Oliva, A., Betrisey, B., Borens, O., Trampuz, A.,
2014. High activity of fosfomycin and rifampin against methicillin-resistant Staphylococcus aureus (MRSA) biofilm in vitro and in experimental foreign-body infection model. Antimicrob. Agents Chemother. 58 (5), 2547-2553.

Miller, G.L., 1959. Use of dinitrosalicylic acid reagent for determination of reducing sugar. Anal. Chem. 31, 426-428.

Mirsada, H., Dzenita, S., Amra, R., Avdić, I.M., Serkan, D., Jasna, H., Feric, B.E., 2018. The effect of lysozyme on reducing biofilms by Staphylococcus aureus, Pseudomona aeruginosa, and Gardnerella vaginalis: an in vitro examination. Microb. Drug Resist. 24, 353-358.

Mitrofanova, O., Mardanova, A., Evtugyn, V., Bogomolnaya, L., Sharipova, M., 2017. Effects of Bacillus serine proteases on the bacterial biofilms. Biomed. Res. Int. 8525912.

Molobela, I.P., Cloete, T.E., Beukes, M., 2010. Protease and amylase enzymes for biofilm removal and degradation of extracellular polymeric substances (EPS) produced by Pseudomonas fluorescens bacteria. Afr. J. Microbiol. Res. 4, 1515-1524.

Mottram, D.S., Wedzicha, B.L., Dodson, A.T., 2002. Food chemistry: acrylamide is formed in the Maillard reaction. Nature 419, 448.

Niemi, P., Tamminen, T., Smeds, A., Viljanen, K., Ohra-aho, T., Holopainen-Mantila, U., Faulds, C.B., Poutanen, K., Buchert, J., 2012. Characterization of lipids and lignans in brewer's spent grain and its enzymatically extracted fraction. J. Agric. Food Chem. 60, 9910-9917.

Ouattara, H.G., Reverchon, S., Niamke, S.L., Nasser, W., 2017. Regulation of the synthesis of pulp degrading enzymes in Bacillus isolated from cocoa fermentation. Food Microbiol. 63, 255-262.

Prajapati, V.S., Trivedi, U.B., Patel, K.C., 2015. A statistical approach for the production of thermostable and alklophilic alpha-amylase from Bacillus amyloliquefaciens KCP2 under solid-state fermentation. 3 Biotech. 5, 211-220.

Rahmati, P., Sajedi, R.H., Zamani, P., Rahmani, H., Khajeh, K., 2017. Allosteric properties of Geobacillus maltogenic amylase. Enzym. Microb. Technol. 96, 36-41.

Rajagopalan, G., Krishnan, C., 2008. a-Amylase production from catabolite derepressed Bacillus subtilis KCC103 utilizing sugarcane bagasse hydrolysate. Bioresour. Technol. 99, 3044-3050.

Ravindran, R., Jaiswal, A.K., 2016a. Microbial enzyme production using lignocellulosic food industry wastes as feedstock: a review. Bioengineering 3 (4), 30. https://doi. org/10.3390/bioengineering3040030.

Ravindran, R., Jaiswal, A.K., 2016b. Exploitation of food industry waste for high-value products. Trends Biotechnol. 34, 58-69.

Ravindran, R., Hassan, S.S., Williams, G.A., Jaiswal, A.K., 2018a. A review on bioconversion of agro-industrial wastes to industrially important enzymes. Bioengineering-MDPI 5 (4), 93. https://doi.org/10.3390/bioengineering5040093.

Ravindran, R., Jaiswal, S., Abu-Ghannam, N., Jaiswal, A.K., 2018b. A comparative analysis of pretreatment strategies on the properties and hydrolysis of brewers' spent grain. Bioresour. Technol. 248, 272-279.

Sadekuzzaman, M., Yang, S., Mizan, M.F.R., Ha, S.D., 2015. Current and recent advanced strategies for combating biofilms. Compr. Rev. Food Sci. Food Saf. 14, 491-509.

Scully, D.S., Jaiswal, A.K., Abu-Ghannam, N., 2016. An investigation into spent coffee waste as a renewable source of bioactive compounds and industrially important sugars. Bioengineering 3 (4), 33. https://doi.org/10.3390/bioengineering3040033.

Shukla, S.K., Rao, T.S., 2013. Dispersal of Bap-mediated Staphylococcus aureus biofilm by proteinase K. J Antibiot. 66, 55.

Simair, A.A., Qureshi, A.S., Khushk, I., Ali, C.H., Lashari, S., Bhutto, M.A., Mangrio, G.S., Lu, C., 2017. Production and partial characterization of $\alpha$-amylase enzyme from Bacillus sp. BCC 01-50 and potential applications. Biomed. Res. Int. 2017, 1-9.

Souza, P.M.D., 2010. Application of microbial $\alpha$-amylase in industry-a review. Braz. J. Microbiol. 41, 850-861.

Srivastava, R., Baruah, J., 1986. Culture conditions for production of thermostable amylase by Bacillus stearothermophilus. Appl. Environ. Microbiol. 52, 179-184.

Vaikundamoorthy, R., Rajendran, R., Selvaraju, A., Moorthy, K., Perumal, S., 2018. Development of thermostable amylase enzyme from Bacillus cereus for potential antibiofilm activity. Bioorg. Chem. 77, 494-506. 